\title{
Continuities and Discontinuities: Antiziganism in Germany and Italy (1900-1938)
}

\author{
Jennifer G. Illuzzi
}

Providence College, USA

\begin{abstract}
In both Germany and Italy before WWI, populations labelled as Gypsies found themselves in a "state of exception" which aimed at their elimination from the nation-state by targeting them with policies emanating from the executive. Both states adhered to the liberal idea of equality before the law, but used the flexibility provided by executive authority to pressure Gypsies to leave the state. After WWI, both Germany and Italy were forced to retain "Gypsies" inside the state as a result of changing geopolitical circumstances. However, in fascist Italy before WWII, executive authorities continued to operate in a "state of exception" and ceased adhering to the rule of law, interning Gypsies in concentration camps and seeking to eliminate them through forced assimilation. In Weimar Germany, legislative policies sought to eliminate Gypsies through bringing them inside of the law. The contradiction between increasingly racialized notion of Gypsy inassimilability and forced assimilation's inevitable failures certainly laid the groundwork for extreme measures in both places during WWII.
\end{abstract}

KEY WORDS: antiziganism, Germany, Italy, state of exception, history

In the past ten years, Romani scholars seeking to change the field from within have challenged old certainties about how to tell the story of Romani diasporic life in Europe (Ryder 2019). One of the key shifts accompanying this ongoing 
debate is the necessity of understanding Romani populations not as perpetual victims, but as enmeshed in sets of social and institutional relationships that shaped their lives and futures, much as other citizens (or, non-citizens, depending on the nation-state) (Marushiakova and Popov 2017). As a nonRomani scholar, navigating the line between reproducing the notion of the Roma as "eternal victims" at the hands of hostile state authorities, and the evidence of the historical archives can be challenging. In the case of the relatively new nation-states of Germany and Italy at the turn of the $20^{\text {th }}$ century, state authorities increasingly controlled populations they labelled as Gypsies, significantly limiting their ability to practice their professions and obtain citizenship or housing. State institutions in Germany and Italy, especially at the executive level, sought to marginalize Gypsy populations at the turn of the century, with results that deeply affected the lives of those targeted. ${ }^{1}$ The following analysis, then, is told from the perspective of the state authorities themselves: utilizing their sources and points of view. The actions of state officials in the early $20^{\text {th }}$ century illuminate the continuities of antiziganist policy in liberal, democratic nation-states, whose effects continue to reverberate in the Romani community. I have sought to understand how the nationalization of the state in both Italy and Germany affected their anti-Gypsy policies at the end of the nineteenth and the first half of the twentieth centuries, and how the evolution of those policies following the first World War and the interwar period built on the late $19^{\text {th }}$ century foundations built by state authorities.

Following WWI, Germany and Italy both shifted their policies away from expulsion as the first option, to a policy that dealt with Gypsies inside of the state. This policy shift was, in large part, due to the increasing power of European nation-states to control the borders, making it more and more difficult to expel Gypsies over international borders. Germany and Italy turned increasingly to punishment models that claimed to force Gypsies to conform to a supposed national norm of behavior ascribed to "citizens," while often offering them little opportunity to gain actual citizenship. Concomitantly, the category of "Gypsy" became increasingly racialized in the interwar era in both Germany and Italy, with the rise of pseudoscientific justifications for their innate criminality. The shift is quite significant, as over time, it made it more and more difficult for those labeled as Gypsies to pursue their livelihoods within the

\footnotetext{
${ }^{1}$ I will use the terms Roma/Romani to refer to the ethnic group of diasporic people; I will utilize the term Gypsy when referring to the group created by state authorities to designate an "other" group living within their borders.
} 
nation-state, which reinforced negative stereotypes about Gypsy criminality by increasing economic stress on their community.

\section{AGAMBEN, ARENDT, SCOTT: MODERN NATION-STATES}

A variety of philosophers and historians have noted the potential of liberal nation-states, adhering to the rule of law, to pursue arbitrary policies aimed at the exclusion of minority populations. The Romani community has consistently been a target of such policies since the late $19^{\text {th }}$ century. Hannah Arendt, in Origins, retrospectively, pointed to the nation-state system in the interwar period as creating the conditions for the destruction of European Jews. It was then, she argued, that the nation overtook the state, and overthrew the foundations of European liberalism and equality before the law:

But insofar as the establishment of nation-states coincided with the establishment of constitutional government, they always had represented and been based upon the rule of law as against the rule of arbitrary administration and despotism. So that when the precarious balances between nation and state, between national interest and legal institutions broke down, the disintegration of this form of government and of organization of peoples came about with terrifying swiftness (Arendt 1973).

The philosopher Giorgio Agamben differs somewhat with Arendt's "breakdown" theory. Agamben, starting with Schmitt's famous "Sovereign is he who decides on the exception" (Schmitt and Strong 2006) instead emphasizes that the potential for marginalization was intrinsic to the making of modern nationstates, even before the disruption of WWI, through his use of the concepts of homo sacer, "state of exception," and "bare life".

In Roman law, the figure of the homo sacer, or "sacred man," is he who can be killed but not sacrificed. Key to Agamben's understanding of this figure is the idea that the homo sacer "is simply set outside human jurisdiction without being brought into the realm of divine law," or in other words, is doubly excepted both from human law and divine law (Agamben, 1998). However, the homo sacer cannot exist without his assignment to the category by the sovereign himself. The state of exception is where the figure of the homo sacer takes shape: "being-outside, and yet belonging"(Agamben 2005).

"Bare life," then, in Agamben's theory, is the life of the homo sacer living in the state of exception: a life abandoned to the whims of the sovereign power. "For 
homo sacer, finally, we are confronted with a residual and irreducible bare life, which must be excluded and exposed to a death that no rite and no sacrifice can redeem."(Agamben 2005). For Agamben, the modern rule of law thus contains a critical weakness: executive powers ("the sovereign") have access to the "state of exception" to carry out biopolitical projects. The state of exception is intrinsic to the functioning of the nation-state, rather than a "bad choice" made by nationalizing states in the interwar period, as Arendt asserts.

James C. Scott's arguments about legibility and high modernism intensify the ability of states to place groups of residents into a "state of exception." Increased legibility of those inhabiting state boundaries in Germany and Italy led to the increased efficacy of biopolitical projects pursued by executive authorities. Despite strong resistance from targeted populations like Romani groups, state authorities persisted and attempted to create a category including specific attributes that supposedly made up the Gypsy, so they could develop "solutions" to their supposed problem. In The Art of NOT Being Governed, Scott touches specifically on the case of the Roma, and expands his notions of state legibility projects beyond the West, agreeing with Leo Lucassen's critique that the biopolitical control of "high modernism" is not only associated with illiberal authoritarianism but with all modern bureaucratic state types (Lucassen 2008). His study of Zomia, a hill region of southeast Asia that resisted state legibility projects for centuries, has important repercussions for the study of European Romani populations. As part of the process of the development of the modern bureaucratic state, states by definition drew a line between those who belonged "inside" the state and the "barbarians" who remained outside. For Scott,

"the category of the 'barbarian' can have no permanent referent apart from being 'beyond the law.' It simply refers to those who at any given time are made to stand for an idea....Barbarians are, then, a state effect; they are inconceivable except as a 'position' vis-à-vis the state (Scott 2010).

He argues that by the middle of the twentieth century, remaining outside of the bureaucratic state's legibility schemes had become virtually impossible for anyone, including Romani populations. Both in Italy and Germany, the late $19^{\text {th }}$ and early $20^{\text {th }}$ centuries demonstrate how executive level biopolitical projects aimed at increasing the legibility of Gypsy populations attempted to make them "disappear" from the national community. 


\section{ITALY: PRE-WAR TO POST-WAR: CONTINUITIES AND DISCONTINUITIES}

Before WWI, executive authorities in Italy had employed a series of administrative regulations that categorized Gypsies as stateless outsiders - in fact, the concept of "Italian Gypsies" became a veritable oxymoron, if not in reality, certainly in rhetoric. Italian authorities accomplished the disappearance of "Gypsies" through confiscation of personal documents, administrative circulars to the various Italian prefects, the police, and the judiciary, and they utilized both national and local authorities to accomplish the "disappearance" of Gypsies. In other words, they used the tools of the information state to make those they categorized as "Gypsies" invisible (Higgs 2004). In some ways, then, at least before WWI, they sought to make Gypsies less legibile by removing their claims to belonging. By the eve of WWII, they had shifted to making Gypsies legible, with the same goal of causing them to disappear.

The "state of exception" was deeply connected with the development of the legal system and liberal concern about the equality of citizens under the law. Continental European law was based on a civil law tradition that asked judges to enforce universally applicable legal codes. Alessandro Simoni points out that this commitment to abiding by constitutionally-established norms and practices provided a serious challenge to laws targeting Gypsies (Simoni 2019). National constitutions, which enshrined liberal and universal goals, made creating a separate legal category for a single group ideologically challenging. Legislators navigated around this prohibition by passing laws that criminalized unwanted behavior, rather than unwanted groups (Simoni 2008). Judges who were sworn to uphold the constitution and the civil code often did so in cases involving Gypsies; they could and did throw out arrests that stretched the interpretation of criminal law. They were not protecting Gypsies as such, but the abstract individual shielded by the law.

For example, liberal France had chosen to pass illiberal laws targeting Gypsies, most importantly the 1912 law regulating the carnet anthropometrique for all Gypsies and nomads (Zaretsky and Miljanic 2010). The carnet allowed for the control and monitoring of the Gypsy population - its purpose was to marginalize Gypsies living within the French state, but to separate them simultaneously from the body of the national population. As Martine Kaluszynski points out, the action, nominally basing its criteria on residency alone,

demonstrated the contradictions of a law that sought to injure a group that it had great difficulty defining. For how could one distinguish legally between gypsies and other nomads? This distinction was even more difficult given that 
France was a country of positive law, which made it impossible to introduce a law based on ethnicity (Kaluszynski 2001).

French Gypsies were brought into the legal system of the state, which in turn gave them juridical standing as French residents, something that could be used to persecute, but also resist the encroachments of the state (About 2009). British laws also tended to criminalize unwanted behavior that in practice, targeted Gypsies for exclusion (Mayall 2003).

Both Germany and Italy, at least before the war, chose to avoid both the British and French routes and instead adopted less formalized, "metajuridical" ways to exclude Gypsies from the national body, by utilizing the state of exception provided for the executive within the criminal codes of both countries, allowing for executive intervention in cases affecting "public security" (Fitzpatrick 2015). In both states, officials adopted these methods consciously, because of the flexibility offered by skirting judicial review, the ability to increase or decrease persecution based on public pressure, available funds, or the international situation, and the value placed on maintaining the strictures of the Rechtsstaat in relatively new states attempting to gain international legitimacy and power. In Italy, Italian jurists like Luigi Lucchini, the editor of Rivista Penale, responded unfavorably to the French law, saying that it violated the "expression of liberty which dominates modern times" and which "absolutely overrides the actual need for protection against a class of persons who only may become dangerous"(Fitzpatrick 2013). Lucchini demonstrated a clear reaction against the spirit of positivist criminology and the countervailing liberal conviction that individuals should be equal under the law. The spirit of liberal universalism, combined with the norms of the modern bureaucratic state, kept Italy from following positivist jurist Alfredo Capobianco's advice to create special laws against the Gypsies in imitation and support of the French model (Capobianco 1914).

For example, before the outbreak of cholera in summer 1910 that led to a mass expulsion of Gypsies from Italy, the Austro-Hungarian Ciuron family was traveling around Tuscany with valid passports, exhibiting generally "good conduct," which made it difficult for the authorities to arrest and expel them, according to the reigning executive instructions of the time. ${ }^{2}$ Following a

\footnotetext{
${ }^{2}$ For a fascinating history of the movement of another group with the same family name of Ciuron, see: (Sutre 2014).
} 
request by the prefect of Tuscany to evict the family from rented land near Florence, the family contacted a lawyer who informed the interior ministry in Rome that these were coppersmiths who had resided in Italy since 1905, and they had a decent income and a farm in Galicia. Since they were "hardworking and honest" they had never been hindered in practicing their profession.

Now those gentlemen [the Ciurons], in the name of their troupe, declare to the illustrious gentleman [minister of the interior] that they will remove their tents from Florence by 3 April, and that they will depart, some of them going to Crema and Cremona, and others to Rome, to practice their profession, and they will not forget to alert the local public security authorities according to the law" (Avv. Giuseppe Gregoraci to the Interior Minister, 31 March 1910).

The strategy worked in the short term, and the family received permission to reside in Italy legally. However, in November 1910, the interior minister sent a telegram to the prefect of Rome, instructing him to revoke their residence permits. The rest of the Ciuron family residing elsewhere in Italy had already been expelled (Ministero dell'Interno to Prefect of Rome, 27 November 2010). The cholera outbreak made the executive authorities even more determined to deal with the Gypsies outside of the law (La Stampa, 1910). When Italian executive authorities were working within the confines provided by the legal system, the Ciurons could respond to state repression and persecution by consulting a lawyer to protect their interests; once the authorities sought to control Gypsies outside of the confines of the law, there was little they could do to protect themselves from an arbitrary state of exception. The example illustrates the flexibility provided by executive measures, and the resistance avenues open to Gypsies who could use the judicial system as a mode of resistance when the executive authorities were unwilling or unable to implement executive directives.

Italian pre-war policy can be summed up by Giovanni Giolitti's response to Tommasso Tittoni's inquiry regarding Italian participation in a Swiss conference on the "Gypsy problem" proposed in 1908:

in Italy we do not have a class of persons of Italian nationality that one could consider as belonging to the category of real-existing and proper Zingari. There are, it is true, a few hundred families who, based on the profession in which they are employed (acrobats, wanderers) necessarily lead a nomadic life, but those people are of the Italian nationality and they cannot be considered as or treated in the same manner as the Zingari, who are people of indeterminate origins and nationality. 
Thus the necessary presupposition for participating in the conference is missing, and in fact, the caravans of Zingari which the authorities of Public Security must deal with according to their authority, are constituted of foreigners who have illegally penetrated the kingdom, despite the vigilance exercised at the borders in order to keep them out in accordance with the last part of article 92 of the current law of Public Security (Direttore Generale di Pubblica Sicurezza to Ministero dell'Interno, Rome, 20 August 1909).

Note the clear distinction made between "Gypsies," who were assumed to be of foreign nationality, and Italian nomads, who were, in this categorization, quite different. Participating in the conference, as the foreign minister pointed out, would have meant admitting an undesirable "class of persons" into the Italian state who Giolitti claimed had not been there before by differentiating "Italian nomads" from true "Gypsies." Since the policy was expulsion for all Gypsies, those with Italian citizenship, or at least Italian birth, could not legally be expelled with ease, and thus were categorized as Italian nomads, and released following detention, arrest, or imprisonment. The policy outlined here was fairly consistent with earlier anti-Gypsy policies: as early as 1872 Giovanni Lanza's interior ministry issued a circular to the prefects of the kingdom remarkably similar to the official policy from 1908: "The zingari are vagabonds...they must be punished with jail sentences and expelled from the kingdom: the possession of a regular foreign passport certainly does not subtract from the application of the law" (Ministero dell'Interno to the Prefetti del Regno, 16 August 1872). The circular was issued in response to complaints from the prefects of northern Italy about caravans of Gypsies traveling around with women, children, and animals. The prefects stated that they were causing a distinct threat to public security. The circular, notably, only seemed to assume two definitive characteristics for Gypsies: foreignness and vagabondage. It described the Gypsies in the following manner: "they go around apparently explaining dreams and telling fortunes, or other small labors; but in reality they live by the fruits of begging, theft and fraud; in the cities they are a burden, in the countryside they are dangerous." The interior minister DePretis wrote to the prefects in 1879 , complaining that his earlier orders were not being carried out because of lax security at the borders, and he emphasized the importance of controlling the population: "in reality they live, as was stated already in the circular from 16 August 1872, from begging, swindling, and theft, and are always bothersome and dangerous." He asked the prefects to expel, under the public security law, any Gypsies who eluded the border guards (Ministero 
dell'Interno, Direzione generale di pubblica sicurezza to the Prefetti del Regno, 15 May 1890). Before the cholera outbreak in 1910, Italian policy was fairly clear and consistent (if nearly impossible to implement) and assumed the foreignness of all those placed in the category of Gypsy. Strong claims to Italian citizenship or nationality, under this imagining, occasionally enabled Romani people to disappear into the category of ordinary Italian citizens.

When a 1910-1911 cholera outbreak in Puglia and later Naples was blamed on Russian Gypsies, executive state authorities increased pressure on local officials to implement official policy. By then, countries like Austria, Switzerland, and France had redoubled their efforts to keep Gypsies out of their borders, and the cholera outbreak had raised suspicions of anyone leaving Italy at the time. Thus, both foreign and resident/Italian Gypsies had a difficult time leaving Italy, despite the expulsion orders, and executive authorities and the police sent Gypsies with claims to Italian birth or nationality to Italian ports, particularly Genoa, for transport to destinations abroad like Brazil. Rather than a shift in policy, the cholera outbreak meant Italian authorities attempted to enforce the earlier circulars more rigorously. The undersecretary of the interior, Calissano, issued a circular on August 21, 1910, ordering the prefects to trace the Russian caravan's route and to make suggestions for how to "liberate the territory from these caravans" (T. Calissano, Circular no. 99118 to the Prefects of the Kingdom, 21 August 1910). On August 28, the Interior Minister, Luigi Luzzatti, issued an even more strongly worded circular to the Prefects of the Kingdom in which he sought to "recall attention...to my firm proposal to liberate Italy from Gypsies and to impede their entrance into the kingdom." The minister required each of the prefects to explain what their province was doing to achieve these goals (L. Luzzatti, to Prefects of Torino, 28 August 1910). In October of 1910, the minister Leonardi from the Office of Public Security in Rome sent a telegram to the prefects in Piedmont and Liguria with specific dispositions outlining departure points for German and Swiss Gypsies scheduled for expulsion, and ordered the sale of most of their property to pay for their internment, evoking what the French would codify as part of the 1912 law (Leonardo to Prefetto di Torino, 4 October 1910).

Under this policy, families with strong evidence of Italian nationality, like the Roma Levakovich family, who lived in Friuli borderland between Italy and Austria-Hungary, were rejected from the Austro-Hungarian border repeatedly, until Italian authorities ended up embarking them on a ship to Santos (Brazil), which departed on 25 February 1911 (Prefetto di Udine to Ministero dell'Interno, Direzione Generale di pubblica sicurezza, 24 August 1911). Liberal 
immigration policies in South American countries allowed many Italian immigrants to purchase land and work farms there during the Italian winter, and come back to work the harvest in Italy in the spring (so-called golondrinas). Gypsies with claims to Italian nationality existed outside even the category created by Italian officials, and created a conundrum in a time of crisis, when executive authorities wanted to rid Italy of people who appeared to be Gypsies because of sociological traits and/or behaviors. The tensions created by Italian Gypsies during the cholera crisis are key to understanding Italian behavior after WWI.

The few Italian scholars who have researched Gypsies in interwar Italy do not always take account of the pre-war situation of Italian Gypsies, which is quite understandable given the archival difficulties of researching ANY time period in regard to Italian Gypsies, who, as I noted above, have virtually disappeared from the Italian archival record due to the nature of their categorization. Paola Trevisan has pointed out the continuities in liberal and Italian fascist policy (Trevisan 2013, 2017, 2019). She mentions two 1926 circulars which aimed at only foreign Gypsies, like the prewar circulars. The wording is strikingly similar to that of the 1910 administrative measures: it requests that the prefects "purge the national territory of the presence of Gypsy caravans, who, it would be superfluous to remind you, pose a danger in regard to security and public hygiene because of their characteristic behaviors" (Guerrazzi 2004). Thus, it seems that the creation of a "state of exception" for Gypsies on Italian territory continued. In many cases, those expelled were not accepted by any other territory, placing them in the condition of homines sacri, subjected to the arbitrary will of the executive. As Rosa Corbelletto points out, in order to get rid of unwanted Gypsies, public security authorities often had to, in the dead of night, sneak them over the Austro-Hungarian border, using mountainous, treacherous trails, endangering the life of the old, the very young, and the infirm (Corbelletto 2008). The prewar model, continued into the 1920s, proved unsustainable. After these long treks, Gypsies would often be caught on the other side of the border and returned to Italian territory. The one advantage of this policy for Romani families who had claims to Italian nationality was that some were able to assimilate and escape their categorization as Gypsies. The growing apparatus of state control and attempts to bring uncontrolled populations under state surveillance mean that informal executive measures, like expulsion, worked less well when the receiving states more easily rejected noncitizens. In his work Tzigari: Vita di un nomade, co-written with Giorgio 
Ausenda, Giuseppe Levakovich describes the changes in the northeastern borderlands following WWI:

In those years [early 1930s] there were very few ceremonies among the Rom, who were forbidden to leave the province [of Buje], like they had during the days of the Austro-Hungarian government. Both the Slovenians and the Italians remembered the Austro-Hungarian administration fondly, because before there was more work and we were better off. Often we played a few AustroHungarian marches (Levakovich and Ausenda 1976).

By 1935, Levakovich argued that "greater liberty" for the Roma had come into existence, and he moved from Buje to Udine, where there was more money, more jobs, and a better horse market for him to practice his trade. When he returned to visit his family in Buje in 1936, he was alerted that he could sign up to work building railroads in Ethiopia. Levakovich volunteered, and thus received his proper identification papers and Italian citizenship, during the fascist regime. He married his wife formally in a church, so that if he died abroad his family would get death benefits. Levakovich's changed life, however, did not come without a price. When he is off fighting, he received word from his sister in law that in spring of 1938, "on orders from Mussolini, all of the Rom that did not have a permanent job had been sent to concentration camps in southern Italy, in Teramo, Calabria, or in Sardegna. My family was sent to Mangone in the province of Cosenza. For me, it was as if I had taken a shot from a rifle. It seemed to me to be a terrible betrayal by a government I was working for." The account offered by Levakovich and his co-author, Giorgio Ausenda, must be placed in its proper context. Published in 1975, it was part of a wave of "autobiographical" writing by Roma that coincided with a political push for greater acceptance in European states. The narratives, as Paola Trevisan points out, are designed to engage a non-Romani audience while simultaneously maintaining Levakovich's unique status as a Romani man. Ausenda's invisible and undisclosed editorial choices, language usage, and translation strategies shaped the text for his non-Romani readers, and Levakovich also shaped his story to be accessible for a non-Romani audience (Trevisan 2009). From Levakovich's account emerged the carrot and stick strategy of the fascist state as it evolved in the 1930s: get Italian Gypsies to "settle" and take up regular work, or intern them in a concentration camp until they learned how to be "civilized"(Trevisan 2016). 
It is important to note the differences from pre-WWI policy. Post WWI Italy was at the heart of a changed Europe, and Italy itself experienced a period of great instability before Mussolini's takeover in 1922. Passport and border controls instituted during the war, the rise of new nation states in eastern Europe and the Balkans, and the development of "national minority policies" all had negative effects on Gypsies, as Levakovich alluded to. The multinational Austro-Hungarian empire was replaced by nationalist governments intent on creating homogenous state identities. The massive population displacement of the post-WWI era led to significant restrictions on migration, and the freedom of movement laws that had been one of the hallmarks of liberal state building were greatly restricted (Irsigler, 2007). Thus, as the fascist state soon realized, the old liberal state's policy of not admitting the existence of Gypsies with claims to Italian nationality had become virtually impossible. Gypsies who had been born in Italy, and had claims to Italian nationality, were not just going to leave, and backdoor solutions would no longer be sufficient. Perhaps somewhat ironically, the fascist state found itself in the situation the Swiss had been trying to prevent in 1908: having a significant number of stateless Gypsies on their territory that they now had to do something about.

By 1937, argue both Guerazzi and Trevisan, a policy change became necessary. The head of the Italian police, Arturo Bocchini, issued three circulars between 1937 and 1938. In the first circular, he attributes "the most serious crimes by innate nature and methods of organization and execution" to Gypsies

who are easily able to escape the investigations and evidence of the Police because they are without a residence or dwelling. In order to stamp out criminal activity that is particularly harmful because it occurs in the border areas, the dispositions imparted in previous circulars dealing with keeping out and expelling foreign Gypsies should hold, however, it is necessary that those girovaghi [travelers] of either presumed or definite Italian nationality be rounded up as quickly as possible and concentrated in an appropriate location in each province to keep them from moving, adopting the formula for their assignment provided by article 181 no. 3 of the law of Public Security, and placing them under rigorous controls (Guerrazzi 2004; Trevisan 2017).

Bocchini's circular highlights much continuity with prewar policies. First, Bocchini is careful to reinforce the previous circulars outlining Gypsy policy: all foreign gypsies should be kept out or expelled. Second, Bocchini uses an administrative circular, not a formal legal procedure, however, under fascism the difference between these two is greatly diminished. Third, Bocchini, like 
those before him, relies on the provisions of the public security law to justify his actions. Fourth, it seems that Bocchini is careful to use the word girovaghi when referring to those of Italian nationality - a careful splicing of words that also distinguished liberal approaches to Gypsy control. In Giolitti's response to the foreign minister in 1909, he distinguishes zingari from Italian nomadi, as if to assert difference. It seems to me that while Bocchini in practice seems to admit the category of "Gypsies of Italian nationality" (and as I'll explain below, this is widely how the regulations are perceived), he is careful to try to make a distinction between girovaghi of Italian nationality and "Gypsies." It also seems clear that Giuseppe Levakovich's story about the fate of his family largely squares with the changes in Italian policy taking place over the late 1930s. Levakovich's job guarantees him status as an Italian citizen, while his wife and children's unemployment means that they are sent to internment camps (Trevisan 2013).

The shift in Italian policy in 1937 and 1938 is reflected in the newspaper coverage of La Stampa, the Torinese newspaper, in those years. La Stampa went from being a liberal to a fascist mouthpiece under the ownership of the Agnelli brothers. They are one of the few Italian newspapers to have a complete online and searchable database, which allowed me to ascertain some interesting peaks in publication on Gypsies (see appendix 1). The first big spike happens in the five year increment from 1910-1914, which coincides with the expulsion of Gypsies in 1910 and 1911, following the cholera outbreak in Puglia. The years of World War I include a precipitous drop-off in the number of articles mentioning Gypsies, and then for the next 15 years the numbers steadily rise, peaking in 1930-34, and dropping slightly from 1935-1939. In the years of the Bocchini telegrams, there were 145 articles, almost as many as were in the 5 years between 1910-1914. Although some of the articles cover films, theater pieces, or music, the frequency of those topics in the arts would also lend themselves to a general public interest in the "mysterious" world of Gypsies. During WWII, mentions of Gypsies again drop, but still only slightly below the previous peak of 1910-1914.

Two series of articles from 1937 and 1938 clearly attest to the interest of the reading public and the fascists in general for the "Gypsy question". Between March and May of 1937, the journalist Paolo Zappa, a foreign correspondent for La Stampa and an early and ardent adherent of fascism, published a twelve part series entitled "Le Carovane degli eterni erranti" - "The Caravans of the Eternal Wanderers." Attilio Crepas, another special correspondent for La Stampa, published the second series, in five parts, entitled "Bonifiche Umane: gli zingari, 
ancorarli al terra" - "Reclaimed Humans: the Gypsies, anchoring them to the land" between January and February of 1938.

Zappa's series was focused on "foreign" Gypsies, and he went to Hungary, to the "winter camp" of Hungarian Gypsies in the town of Satoralijaujhely. He remained with them there, reporting also from Bucharest, until April, when they set out on their spring and summer travels throughout Romania. Zappa styled the articles as a pseudo-anthropological study of the secrets of foreign Gypsies, and the articles are usually themed around a single aspect of "Gypsy life." His account clearly racializes the Gypsies, calling them an "unchanged race"(Zappa 1937c) asserting that as "primitives, in a super-civilized world, the gypsies cannot resist the call of their race". He asserts that one "hears the call of the race, always present because it circulates in them with their blood, always insistent because it beats so closely with their heart"(Zappa 1937b). Zappa gives the readers details of their "fear of water: they never wash themselves," and informs the readers that "theft along with begging represents for the gypsies the most common industry and the most honorable profession"(Zappa 1937f). Mixed with his own ethnographic study, he cites secondary sources to tell the history and origins of the Gypsies. He even has an "adventure" with a Gypsy woman, alà Carmen, to satisfy his readers: after unbuttoning her blouse, he tells us, "And, so, I would have fallen into temptation, if a powerful interruption did not save me from the edge of the abyss". The bar owner warned him that the Gypsy woman was running an extortion scam with her husband waiting outside (Zappa 1937a). Zappa's articles embraced every stereotype that had been circulating about Gypsies in modern Italy, including child stealing, musical talent, their lack of religion, and their social organization equal to that of "primitive man"(Zappa 1937d).

In a piece on Gypsy origins, he discusses the relationship between Jews and Gypsies. Quoting Wagenseil, the $17^{\text {th }}$ century anti-Semite, he tries to disprove the theory that Gypsies are cousins of the Jews. He points out that while Jews accept society, so that they can come to control it, the Gypsies reject social organization altogether. Unlike Jews who "pretend to have received their law from God," Gypsies have "no doctrine, no faith, no religion". He argues that their complete opposition to one another makes Wagenseil's assertion impossible, and concludes by arguing that the Gypsies "have never, in fact, changed"(Zappa 1937e). Zappa's series is racial pseudoscience at its most abhorrent. Zappa's series reinforces the historiographical consensus that the interwar period solidifies the racialized identity of zingari, to a mass reading public. As I have argued elsewhere, the growth of a literate public during the 
early $20^{\text {th }}$ century meant wider circulation of newspapers and a homogenization of ideas about Gypsies that "trickled down" from elite sources (Illuzzi 2019). Zappa's approach, however, reflects Italian ambivalence about who could be a Gypsy - by clearly positing them as outside of the Italian national body, as "exotic" and "dangerous" foreigners. Zappa's story deals purely with foreign, Romanian Gypsies, rather than with the newer category of Gypsies admitted by the Bocchini circulars of 1937 and 1938.

The following year, La Stampa readers encountered another five part series on Gypsies. Attilio Crepas, unlike Zappa, focused completely on Italian Gypsies in the province of Gorizia. The "human reclamation of the Gypsies, striving to "anchor them to the land" seemed almost completely a world apart from the idea that the Gypsies were "unchangeable wanderers" who physically lusted after roaming. The turn from "expelled foreigners" to "dangerous Italians" completed at the time of the Bocchini circulars is reflected in the drastic change in tone of the Crepas articles (Trevisan 2017). Key to understanding Crepas' approach were the changing geopolitical circumstances of the fascist state: Gorizia was acquired by Italy after WWI, and it becomes "a test case for the fascist regime, which increasingly emphasized the importance of their Italianization" (Trevisan 2016). Crepas' central argument in the series is that Italian Gypsies in the northeastern provinces, by means of a "carrot and stick" approach, could and would be civilized by the beneficent fascist regime. Crepas visits the "concentration camps" of Gorizia and documents the stories of Gypsies happily settled around their new fascist hearths, attending school, and adopting the new camp slogan of "work and hope." When Crepas tries to get a young woman to translate the slogan for an older woman in the camp, she responds, "signore, this word [hope] doesn't exist in the language of the Gypsies"(Crepas 1938a). Crepas acknowledges the stereotypes outlined by Zappa: the kidnapping, the theft, the wanderlust. But, he argues,

The fascist regime will give these squalid creatures of misery born in Italy their human dignity, and instead of persecuting them mercilessly, it will assign them to a place where they can settle, and provide them a home and employment. All in all, they will be anchored to the land. The State will provide them with tools, a little help, a generous fascist allowance for a civil life.

Also, in certain "democratic" states, the gypsies have been tied to the land. Without any concern for their marital status, without aid, without tools. All they get are a few bullets and a ditch (Crepas 1938d). 
The challenge to the racist narrative of Zappa is clear: race is by definition unchanging, and yet changing Gypsies' nature was precisely how the fascist government portrayed the internment camps. As Trevisan asserts, the increasingly capacity of the $20^{\text {th }}$ century information states necessitated new solutions for zingari (Corbelletto 2008; Trevisan 2017). The Crepas articles demonstrated an immediate response to the policy shift outlined by Bocchini. Crepas began his series in Innsbruck, where he spoke to the Austrian border police just two months before the Anschluss. They supposedly sang the praises of the fascist government that solved the problem of the constant back and forth border expulsions. Again, Crepas focused on the failure of the democratic states to resolve the problem: "democratic laws, unable to provide for a radical solution to the problem, have simply organized an actual clandestine exodus to Austria". Crepas proclaims that 1938 will spell the end of the Gypsies. He asks "are they a people, a race? No. Are they a sect? Not that either. A religion? Certainly not. And so? They are a kingdom" (Crepas 1938b). The shift from the racialized Gypsies of Zappa's imagination to the vision of assimilation by an all-powerful fascist state provides the logical justification for internment of Gypsies in Italy, some "accidentally identified as Italian, and others more rarely who actually have Italian citizenship"(Crepas 1938d). The solution was in keeping with Scott's ideas about the unprecedented power of the modern state "to realize a project of rule that was a mere glint in the eye of its precolonial ancestor" - or even, in this case, a glint in the eye of the liberal state (Scott 2010). As Crepas hints ominously himself: "the plague that the fascist reclamation is curing needs to be cauterized at its cancerous margins. It is necessary to annihilate the typical Gypsy delinquency." He describes how the first "cauterization" was quite severe - Gypsies in Trieste were tried for their "grave crimes" (it is not clear which crimes) and the public minister requested the death penalty. Instead, they were sentenced to life in prison and 158 years for their lesser crimes (Crepas 1938c). The supposed carrot of the internment camps which would "assimilate" Gypsies to an Italian lifestyle was accompanied by the stick of the severest penalties for those who resisted fascist power.

In the case of interwar Italy, the liberal state of exception was resolved when the fascist state itself was transformed into a "state of exception" - to put it in Agamben's terms, the dialectic between auctoritas (the biopolitical authority of the sovereign power) and potestas (power that has its roots in the normative political system of law) breaks down in the fascist state, and the "duce" becomes the embodiment of both power and authority. The need to remain within the legal strictures laid down by the liberal stato di diritto as a way to navigate 
between the sovereignty of the body politic and the literal body of the executive authority is destroyed. Agamben states, "when they [auctoritas and potestas] tend to coincide in a single person, when the state of exception, in which they are bound and blurred together, becomes the rule, then the juridico-political system transforms itself into a killing machine" (Agamben 2005). There is no more need to work around or outside of the law in the case of Gypsies, because the Italian executive powers, including the police, can act without the intermediary functions of the legislative or the judiciary. While, as Crepas asserts, the end of the Gypsies is somewhat of a metaphorical death in Italy, the executive powers aimed to eliminate the category which was only first admitted to exist under the fascists themselves. In the liberal period, because of the location of the "state of exception" outside of the law, the goal was to "foreignize" and expel as many Gypsies as possible. However, given changing geopolitics, the fascist police authorities admitted the existence of Gypsies who had claims to Italian citizenship, and aimed to control and "civilize" as many Gypsies as they could through internment. The flexibility so important to the liberal system, remained, however, within the totality of the state of exception: "In fact, the lack of specific legislation and the consequent absence of criteria to enable the definition of who was an 'Italian Gypsy' gave the Prefects total liberty in deciding who the police measures should apply to. This situation made it even more difficult to document persecution, and it has increased the memory lapse about the entire event"(Trevisan 2013). The outcome for the Gypsies then, was strikingly similar to the outcome in the liberal state, in that they were effectively "disappeared" from Italian history, but the fascist state changed the positionality of the margin: placing interned Gypsies inside the state, while delegitimizing their claims to citizenship, whereas the liberal executive attempted to physically push Gypsies outside of the state utilizing the "state of exception".

\section{GERMANY: CONTINUITIES AND DIFFERENCE}

In the late $19^{\text {th }}$ century, Germany was also becoming a unified nation-state and making critical decisions about how to shape state institutions and distribute state power. The historiography of Germany and Italy often focuses on their "failed liberalism, "but that assumption has been more recently questioned (Smith 2008; Carter 2011). Archival sources in Berlin and Bavaria outline an expansive state interest in Zigeuner control at the turn of the century: press clippings, various executive circulars, communications between the Bavarian 
Zigeunerzentrale and various ministries, inter-ministry communications, and communications from abroad, all clearly alluded to a vigorous debate about a supposed problem in need of control and monitoring (Illuzzi 2014). They also demonstrate that, unlike in Italy, German authorities in the $19^{\text {th }}$ century directly acknowledged a category of persons designated as Zigeuner who resided permanently within the nation-state. In order to rid the nation-state of Gypsies, Italy sought to make "Gypsies" disappear, while Germany sought to make them more visible (Heuss 2000). Germany and Italy utilized the tools of the information state to place Gypsies in a "state of exception" outside of, but tied to, the national community.

Understanding German prewar examples show again the flexibility and the deliberateness of the choice to avoid legislative solutions to the Gypsy problem. Alfred Dillmann, the Munich chief of police and head of the Ziguenerzentrale before WWI, sought, in a 1911 conference with states bordering Germany, to establish a Reich center for Gypsy control, based on the model of the Munich Zigeunerzentrale, which would provide for coordination and control, particularly among the police forces. Dillmann stated that the conference program

comes from the standpoint that the solution of the Gypsy question cannot be undertaken through legislation on the level of the Reich or the individual states, but that this goal is best achieved through the creation of a list of unified administrative regulations" (Dillmann 1912).

In a footnote, he explained that the attempt to pass a law of exception [Ausnahmegesetz] in the Reichstag in 1910 was unnecessary, "even though it cannot be debated that the Gypsies, who are on the lowest rung of culture, are not ready for the newest phase of development of the German people, freedom of movement and free trade"(Dillmann 1912). Passing a law codifying the state of exception, in Dillmann's view, would stabilize the category of Gypsy in a way that might enable some Zigeuner to access legal protection, making arbitrary executive action more difficult. During discussions at the conference, the Prussian representative

alluded that through a powerful executive Prussia had succeeded in keeping Gypsies out; if they entered out of their own free will, they would shortly leave of their own free will. As far as international regulation, his government [Prussia] does not see any advantage; the most important role in the struggle against the Gypsies is always the executive [Executive], which in Germany is 
much stronger than abroad"("Niederschrift über die Besprechung im K.B. Staatsministerium des Innern am 18. und 19. Dezember 1911, betreffend die Bekämpfung der Zigeunerplage", 1911).

The Prussian official was unequivocal: a strong executive, like that in Germany, could deal much more readily and harshly with Gypsies than other places with strong legislative and judicial powers. The rule of law established in modern nation-states, like Italy and Germany, proved to be more of a hindrance than a help when dealing with undesirable populations who were not considered part of the "national body." The stronger the executive, the more able it would be to impose a state of exception upon the undesirable populations, thus excising them from the nation. In Germany, decrees from the individual states making up the Reich served this purpose, yet, as of 1910, also seemed, at least in the perception of officials, to be having little effect, thus necessitating coordination - but not a turn to legislative solutions. However, during the Weimar period this changed with the passage of the 1926 Law for the Struggle against Gypsies, Vagrants and other Workshy. The Bavarians were followed by other German states like Mecklenburg-Schwerin (1927) (Irsigler 2007).

The dissolution of the Italian state into the "state of exception" under Mussolini has clear parallels with Germany after 1933, where Gypsies were no longer denationalized and expelled as they were under the Kaiserreich, but interned and killed. The pre-war German Gypsy policy outlined above was actually similar to Italian fascist Gypsy policy after 1937 in the sense that Germany admitted the existence of a resident Gypsies. Because the Kaiserreich, however, like liberal Italy, "was a Rechtsstaat characterized by multiple, constitutionally delineated sites of sovereign power that were subject to intense and often effective forms of political scrutiny and civic pressure," officials hesitated to round up and intern the Gypsies in the same way as the Italian fascist state (Fitzpatrick 2013). However, the state did rely on criminalization and the option to send recalcitrant Gypsies to the workhouse. In the case of German Gypsies, the strategy was one of denationalization - by confiscating identifying documents over time, the Gypsies found it harder and harder to prove their German nationality, and ended up in a cycle of expulsion paralleling the Italian case.

Germany's post WWI history differed in key ways from that of Italy. Understanding that history is central to understanding what seems to be a radical shift in policy in Germany. Rather than employing the "state of 
exception" to remain nominally within the law while simultaneously marginalizing Gypsy populations outside of the law, the Bavarian state, followed by other border areas, passed a Gypsy and Workshy law in 1926. However, the Weimar state adhered at least nominally, to the norms of the Rechtsstaat. So, how did the choice to bring Gypsies inside the law come about? Democracy itself may have had something to do with it: public pressure for "law and order" after the disorder of the revolutions of 1918-9 and the brush with Eisner's radical socialism, was quite high, and particularly in Bavaria concerns about the "Gypsy nuisance" were prominent during the Kaiserreich. Bavaria, before WWI, had established the Zigeunerzentrale with aspirations of becoming the Reich center for Gypsy control - which was achieved temporarily with the passage of the 1926 law. ${ }^{3}$ In Bavaria, democratic pressure from below and among the representatives to the Landtag to finally control the vagrant and Gypsy problem were quite popular, and the "strong executive" that allowed police officials like Dillmann a relatively free hand in the Kaiserreich were gone. The executive was weak, and the legislative was the strongest expression of power at the time. The "sovereignty" of the state had moved from the body of the Kaiser (auctoritas), to the power of the people (potestas), located in the legislature. The Weimar constitution, signed in 1919, stated in article one that the "power of the state emanates from the people". Since "the people" were most closely tied to the Landtag, the choice to pass an anti-Gypsy law seemed more plausible than before the war. It actually gave the sovereign power (the legislature) control over Gypsies, but brought them inside the state. While the goal in Bavaria and elsewhere was to force Gypsies to settle and increase "legibility," the efficaciousness of the 1926 law (like the 1912 law in France) was doubtful. As Herbert Heuss points out, there is no clear evidence that the law was applied in a widespread fashion. Instead, the function of the law was to "implement a change in the function of the police. It was now possible for the police not only to prosecute offenders, following the commission of a criminal offence, but also to take independent preventative action"(Heuss 2000). For Heuss, the Weimar law was not primarily about racial persecution, but instead about larger social and economic issues going on during Weimar and the implementation of a positivist vision of law enforcement. Anti-Gypsyism became a way to express anxiety or the need for order. "For as long as the Weimar republic existed, and basic rights were guaranteed under the constitution, Roma were discriminated against and ostracised, but their existence as such was not put into

${ }^{3}$ The Reich center for Gypsy control was eventually moved to Berlin and combined with the Reichskriminalpolizeiamt in 1938 (Luchterhandt 2000). 
question"(Heuss 2000). Heuss's contention is hotly contested among German scholars of anti-Ziganism, but lends credence to Scott's claim that there is little content to the category of "barbarian" other than being "outside the law". Hehemann, Schenk, and Zimmermann tend to automatically assume the racist underpinnings of the law, which, in turn makes the path to Nazi genocide seem much more well-defined (Hohmann 1981; Hehemann 1987; Schenk 1994). The law, while tending certainly towards a racialization of Gypsies in general, more closely aligns with Heuss' thesis. As in Italy, the "racial" categories ascribed to Gypsies still admit the assimilability of the Gypsy, even if the consequences of assimilation are the disappearance of the "Kingdom" of Gypsies, to use Crepas' term.

Heuss's contention seems to be supported in the report offered by the Parliamentary Commission tasked with considering the constitutionality of the 1926 law (Stenographische Berichte zu den Öffentlichen Sitzungen 1925/1926 Nr. 106-129, 116. Sitzung, 12.5.1926, 1926). In the years before 1926, Bavaria and other borderland provinces had passed many administrative restrictions against Gypsies: they could not stay in recreational towns or areas, they were not allowed to carry weapons, and they were all fingerprinted, photographed, and provided with identification papers that marked their status as Gypsies: a clear violation of the Weimar law stating that no one was required to prove their identity with particular papers (Irsigler 2007). The Prussian anti-Gypsy regulations first promulgated in 1906 were renewed. In large part, these policies marked a more intensive continuation of pre-war policies. Gypsies were outside of the law, and outside of the state. However, as in prewar Germany, executive officials were frustrated by their lack of control, and the tendency for Gypsies to fight their categorization, orders of expulsion, and criminal convictions. The 1926 law emerged as a practical solution to the prewar frustration of the executive powers. The legislature sought to ensure "peace and stability" in visible ways - by removing those who signified "disorder and instability."

In seven pages of debate about the law, the word Gypsy is only mentioned at the beginning, where it is stated that the concept of Zigeuner was clearly defined by "racial science." There is not a representative in the Landtag who seemed at all concerned about the law's effect on Gypsies. Instead, the main sources of contention about the law focused on article 10, which stipulated that

the workshy older than 16 , who are unable to demonstrate evidence of regular work or genuine effort at finding work, can, for reasons of public security, have the penalties outlined in Art 8, section 1, paragraph 2 and 3 [can be banned from particular kinds of travel, or residence in particular locales for 3 years, or if 
foreign, could be expelled] or in Article 9, paragraph 1 and 2 [up to two years in a work institution or otherwise employed in an institution] applied after they have been confined to prison. The same is also valid, when these persons are convicted of robbery, extortion, theft, fraud, recitation of stolen goods, pederasty, procuring, pimping, prostitution, gambling, vagabondage, delinquency [arbeitscheu] or begging (Stenographische Berichte zu den Öffentlichen Sitzungen 1925/1926 Nr. 106-129, 116. Sitzung, 12.5.1926, 1926).

The most prominent concern was over the line dividing the workshy from the long term unemployed, and even a worry (on the extreme right) that casual workers skipping work to go hunting or fishing might find themselves in a workhouse as well. Essentially, the problem was with the seeming arbitrariness of the law: it was difficult to ascertain who it applied to and why. How would the police distinguish between the unemployed and the workshy? And would criminals just emerging from prison end up right back in the workhouse? How would they escape a cycle of criminalization? These concerns were mainly raised by members from the SPD and the Communists, but even individual members of the conservative Farmers' party and the National Socialists were concerned. In the end, however, the law passed with minimal changes.

The key provision of the law lay in its excision of the judiciary from the criminal prosecution of the workshy. The move was a direct workaround for prewar frustrations on the part of executive authorities and the police, who were thwarted in their "legibility" projects by a judiciary who tended, at least sometimes, to uphold the strictures of the Rechtsstaat. The law put all of the power for control of the workshy in the hands of the police. The Justice Minister, present at the discussion, asserted that they had no problem with the constitutionality of the law, and in fact, that the police very much needed the power to independently get rid of unwanted people in urban areas. He argued that the Landtag should not wait for the Reich to get its constitutional law and criminal code "in order" - that immediate action was necessary (Stenographische Berichte zu den Öffentlichen Sitzungen 1925/1926 Nr. 106-129, 116. Sitzung, 12.5.1926, 1926).

Aside from the arbitrariness of the law, and its skirting of the judiciary, the SPD also objected to the law's clear restriction on the freedom of movement. They argued that the constitution guaranteed that "every German in every state of the Reich [sic] has the same rights and duties as the residents of the individual state itself'(Stenographische Berichte zu den Öffentlichen Sitzungen 1925/1926 Nr. 
106-129, 116. Sitzung, 12.5.1926, 1926). Allowing the police to determine the travel routes for Gypsies and workshy, as well as limiting their access to certain locales, constituted a clear violation of this provision. The Bavarian interior minister argued that the constitution did not explicitly forbid restrictions on the freedom of movement and that provisions regarding freedom of movement were unclear and had led to confusion on the part of the authorities. The state interior minister contended that the law, rather than being arbitrary or empowering the police too much, in fact, was designed with the "improvement" and "welfare" of the workshy in mind. Like the concentration camps instituted in Gorizia and Trieste in 1938 by Mussolini, this law was intended to "educate" the workshy so they could obtain gainful employment. The law is oddly consonant with Crepas' representation of the fascist motivations for the concentration camps: the fascists claimed (falsely) they would make Gypsies into productive citizens by providing them the aid and tools to do so, while a democratic Germany sought to achieve the same thing, but all they give the Gypsies are "a few bullets and a ditch" - in other words, the means to disappear (Crepas, 1938d). The Bavarian law would undoubtedly submit the Gypsies, already closely surveilled and submitted to intensive legibility schemes, to more or less lifelong confinement in workhouses, unless they decided to leave an increasingly unhospitable Germany.

The Bavarian law illustrated larger issues with the Weimar republic, as Heuss asserts. The Rechtsstaat was under fire as the political, economic, and social systems were weak in the wake of the hyperinflation, and the relationship of authority constructed in the Kaiserreich broke down, and power shifted to the potestas (the legislature), without a countervailing relationship with auctoritas (the executive power and/or the judiciary). In the Bavarian Gypsy law, a clear violation of the norms of the Rechtstaat was admissible because the "state of exception" was no longer needed: the Bavarian state would not be checked by a higher power and forced to uphold the strictures of the Rechtsstaat. Even the French 1912 law requiring the carnet anthropometrique, while clearly a violation of the idea of equality before the law, stopped short of complete police control and virtual imprisonment of those it decided were "workshy." The French law was also relatively ineffective, since Gypsies could use their position inside the law and state to resist state intervention.

Therefore, what occured in post WWI Germany conformed more to an Arendtian idea of the interwar breakdown in the relationship between state and nation than the Italian case. 
It would seem that the very undeportability of the stateless person should have prevented a government's expelling him; but since the man without a state was 'an anomaly for whom there is no appropriate niche in the framework of the general law' - an outlaw by definition - he was completely at the mercy of the police, which itself did not worry too much about committing a few illegal acts in order to diminish the country's burden of indésirables. In other words, the state, insisting on its sovereign right of expulsion, was forced by the illegal nature of statelessness into admittedly illegal acts(Arendt 1973).

However, in the case of the Gypsies, the interwar situation can ONLY be properly explained by looking at the prewar creation of a "state of exception." The undeportability of the stateless person was created by the "outlaw" status of Gypsies before the war. In the case of Germany, the prewar "illegal acts" she refers to were legalized by the legislature. In Italy, the legalization of the previously illegal is symptomatic of the fascist regime in general. Specific laws were not necessary when the state itself became the "state of exception". Viewing post WWI antiziganist policy through its continuities with prewar Gypsy control in Germany and Italy place the racialization and marginalization of German and Italian Gypsy groups in their proper historical context, and help to make sense of the targeting of Gypsies during WWII. However, the liberal state policies do much to illuminate policies in the postwar democratic nationstates. The treatment of Gypsy populations in today's democratic European societies then appears less surprising and as part of a much longer history. In both Germany and Italy, before and after WWI, Gypsies lived a precarious situation that defied the legal norms of the Rechtsstaat. The interwar period, given the tumultuous and difficult situation post-war, caused both states to reimagine their approach to Gypsy control, in radical ways. Arendt's "undeportability" became a reality, and the solution, while positing Gypsies clearly as a racial group, also, at least rhetorically, supported their assimilation in the country. The contradiction between a racial notion of inassimilability and forced assimilation's inevitable failures certainly laid the groundwork for extreme measures in both places during WWII.

\section{APPENDIX 1:}




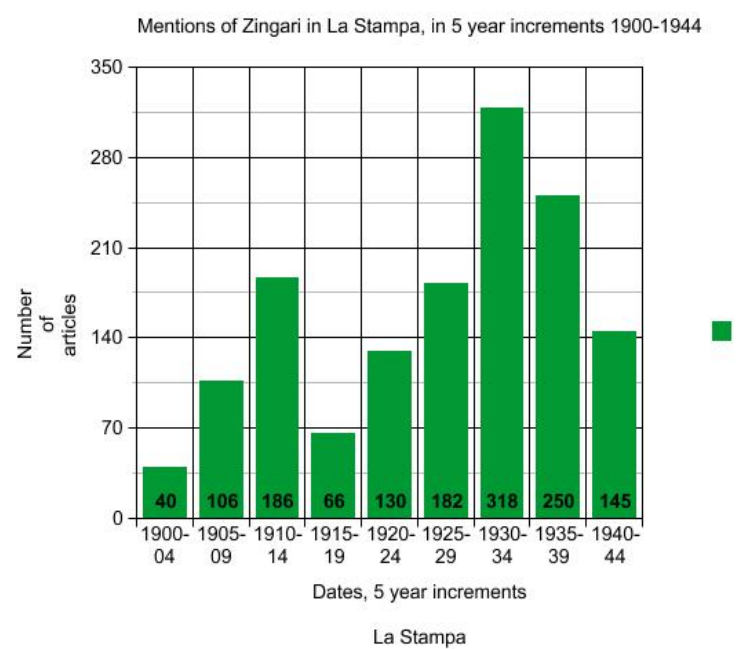

\section{WORKS CITED}

ABOUT, I. (2009): "De la libre circulation au contrôle permanent. Les autorités françaises face aux mobilités tsiganes transfrontalières, 1860-1930", Cultures \& Conflits, (76), pp. 15-38. doi:10.4000/conflits.17757.

AGAMBEN, G. (2005): State of Exception. Primera edición. Traducción de K. Attell. Chicago, University of Chicago Press.

ARENDT, H. (1973): The Origins of Totalitarianism [Los orígenes del totalitarismo]. Houghton Mifflin Harcourt.

CAPOBIANCO, A. (1914): Il problema di una gente vagabonda in lotta con le leggi. Nápoles, Raimondi.

CARTER, N. (2011): "Rethinking the Italian Liberal State", Bulletin of Italian Politics, 3(2), pp. 225-245.

CORBELLETTO, R. (2008): "Rom e sinti perseguitati nell'Italia fascista", L'impegno, XXVII, pp. 76-78.

CREPAS, A. (1938a): "C'era una volta una zingara bionda...", La Stampa, 3 de febrero, p. 2.

CREPAS, A. (1938b): "Fermateli a qualunque costo", La Stampa, 22 de enero, p. 2. 
CREPAS, A. (1938c): "Frantumi del fantastic regno senza frontier e senza capitale", La Stampa, 1 de febrero, p. 2.

CREPAS, A. (1938d): "La donna che si chiamava Amore", La Stampa, 27 de enero, p. 2.

DILLMANN, A. (1912): "Denkschrift über die Bekämpfung der Zigeunerplage", Múnich.

FITZPATRICK, M. P. (2013): "A State of Exception? Mass Expulsions and the German Constitutional State, 1871-1914", The Journal of Modern History, 85(4), pp. 772-800. doi:10.1086/672529.

FITZPATRICK, M. P. (2015): Purging the Empire: Mass Expulsions in Germany, 1871-1914. Oxford, Nueva York, Oxford University Press.

GUERRAZZI, O. (2004): "Il fascismo e gli zingari.", Giornale di storia contemporanea, VII(1), pp. 25-43.

HEHEMANN, R. (1987): Die "Bekämpfung des Zigeunerunwesens" en Wilhelminischen Deutschland und in der Weimarer Republik, 1871 - 1933. Teilw. zugl., Münster/Westf., Univ., Diss., 1986-1987.

HEUSS, H. (2000): "Anti-Gypsyism Research: The Creation of a New Field of Study", en Kenrick, D. (ed.) Scholarship and the Gypsy Struggle: Commitment in Romani Studies: A Collection of Papers and Poems to Celebrate Donald Kenrick's Seventieth Year. Hertfordshire: Univ of Hertfordshire Press, pp. 52-68.

HIGGS, E. (2004): The Information State in England: The Central Collection of Information on Citizens since 1500. Edición 2003. Basingstoke, Hampshire, Nueva York, N.Y: Palgrave.

HOHMANN, J. S. (1981): Geschichte der Zigeunerverfolgung in Deutschland. Frankfurt/Main, Nueva York, Campus Verlag.

ILLUZZI, J. (2014): Gypsies in Germany and Italy, 1861-1914: Lives Outside the Law. Houndmills, Basingstoke, Hampshire, Nueva York: Palgrave Macmillan.

ILLUZZI, J. (2019): "Stories of a Life Together: Romani groups and the poor in turn of the century Italian archival sources", Ricerca Folklorica, 74.

IRSIGLER, F. (2007): "Faule Verbrecher" - Roma und Sinti in der Weimarer Republik. Zur rassistischen Diskriminierung und ihrer praktischen Umsetzung. Norderstedt: GRIN Verlag. 
KALUSZYNSKI, M. (2001): "Republican Identity: Bertillonage as Government Technique", en Caplan, J. y Torpey, J. (eds.) Documenting Individual Identity. Princeton, Princeton University Press, pp. 123-138.

La Stampa (1910): "«La colera va decrescendo la intensità»", p. 2.

LEVAKOVICH, G. y AUSENDA, G. (1976): Tzigari: vita di un nomade. Milán.

LUCASSEN, L. (2008): "Between Hobbes and Locke. Gypsies and the limits of the modernization paradigm", Social History, 33(4), pp. 423-441. doi:10.1080/03071020802410411.

LUCHTERHANDT, M. (2000): Der Weg nach Birkenau: Entstehung und Verlauf der nationalsozialstischen Verfolgung derZigeuener. Primera edición. Lübeck: Schmidt-Römhild.

MARUSHIAKOVA, E. y POPOV, V. (2017): "Rethinking Roma Holocaust: Victims or/and Victors", en Buchsbaum, T. M. y Kapralski, S. (eds.) Beyond the Roma Holocaust: From Resistance to Mobilisation. Varsovia, TAiWPN Universitas, pp. 73-93. Link: https://www.academia.edu/35705190/Rethinking_Roma_Holocaust_Victims_ or_and_Victors (Consultado el 23 de septiembre, 2019).

MAYALL, D. (2003): Gypsy Identities 1500-2000: From Egipcyans and Moonmen to the Ethnic Romany. Taylor \& Francis.

"Niederschrift über die Besprechung im K.B. Staatsministerium des Innern am 18. und 19. Dezember 1911, betreffend die Bekämpfung der Zigeunerplage" (1911). Munich.

RYDER, A. R. (2019): "A Game of Thrones: Power struggles and contestation in Romani Studies", International Journal of Roma Studies, 1(2), pp. 120-143. doi:10.17583/ijrs.2019.4197.

SCHENK, M. (1994): Rassismus gegen Sinti und Roma: zur Kontinuität d. Zigeunerverfolgung innerhalb $d$. deutschen Gesellschaft von $d$. Weimarer Republik bis in d. Gegenwart. Frácfort del Meno [u.a.]: Zugl., Wuppertal, Univ., Diss., 1994 (Studien zur Tsiganologie und Folkloristik, ARRAY(0x558786140c80).

SCHMITT, C. y STRONG, T. B. (2006): Political Theology: Four Chapters on the Concept of Sovereignty. Primera edición. Traducción de G. Schwab. Chicago, University of Chicago Press. 
SCOTT, J. C. (2010): The Art of Not Being Governed: An Anarchist History of Upland Southeast Asia. Edición en Yale Agrarian Studies Series, New Haven y Londres, Yale University Press.

SIMONI, A. (2008): "Sicurezza, legalità e lo spettro degli "zingari”", Reset, 107.

SIMONI, A. (2019): Rom, antiziganismo e cultura giuridica. Prospettive di analisi. CISU.

SMITH, H. W. (2008): "When the Sonderweg Debate Left Us", German Studies Review, 31(2), pp. 225-240.

Stenographische Berichte zu den Öffentlichen Sitzungen 1925/1926 Nr. 106-129, 116.

Sitzung, 12.5.1926 (1926), pp. 450-457. Acceso en: http://geschichte.digitalesammlungen.de/landtag1919/.

SUTRE, A. (2014): "“They give a history of wandering over the world;". A Romani clan's transnational movement in the early 20th century" 2/2014, pp. 471-498.", Quaderni Storici, 2, pp. 471-498.

TREVISAN, P. (2009): "Écrire pour qui ?", Etudes Tsiganes, n 37(1), pp. 90-109.

TREVISAN, P. (2013): "The internment of Italian Sinti in the province of Modena during fascism: From ethnographic to archival research", Romani Studies, 23(2), pp. 139-160. doi:10.3828/rs.2013.8.

TREVISAN, P. (2016): "Le politiche antizingari> del regime fascista nelle province del confine nord-orientale: analisi e prospettive di ricerca", Archivio Trentino, 2, pp. 175-200.

TREVISAN, P. (2017): "“Gypsies" in Fascist Italy: from expelled foreigners to dangerous Italians", Social History, 42(3), pp. 342-364. doi:10.1080/03071022.2017.1327643.

TREVISAN, P. (2019): "The persecution of Rom and Sinti in Fascist Italy", Trauma and Memory, 6(3), pp. 48-55. doi:10.12869/TM2018-3-02.

ZAPPA, P. (1937a): "Il frutto proibito", La Stampa, 4 de mayo, p. 3.

ZAPPA, P. (1937b): "Il richiamo della razza", La Stampa, 9 de mayo, p. 3.

ZAPPA, P. (1937c): "Incontro con la madre della tribù", La Stampa, 16 de abril, p. 3. 
ZAPPA, P. (1937d): "L'ideale di ogni zingara dal marito", La Stampa, 8 de abril, p. 3.

ZAPPA, P. (1937e): "Origine degli Zingari", La Stampa, 13 de abril, p. 3.

ZAPPA, P. (1937f): "Ospitalità gitana", La Stampa, 3 de abril.

ZARETSKY, R. y MILJANIC, O. (2010): "France and the Gypsies, Then and Now", The New York Times, 6 de septiembre. Link: https://www.nytimes.com/2010/09/07/opinion/07iht-edzaretsky.html (Consultado el 3 de octubre, 2019).

\section{ARCHIVAL SOURCES (IN ORDER OF CITATION)}

Letter from Avv. Giuseppe Gregoraci to the Interior Minister, Rome, 31 March 1910, Archivio Centrale di Stato Roma (ACdSR) Ministero dell'Interno 12100.14, Polizia Giudiziaria, 1910-1912, busta 309.

Telegram from Ministero dell'Interno to the Prefect of Rome, 27 November 1910, ACdSR Ministero dell'Interno 12100.14, Polizia Giudiziaria, 1910-1912, busta 309.

Direttore Generale di Pubblica Sicurezza to Ministero dell'Interno, Rome, 20 August 1909, ACdSR, Ministero Interno Direzione Generale "Pubblica Sicurezza” Divisione Polizia Giudiziaria: 1910-1912,12100.14, busta 304.

Telegram from Ministero dell'Interno to the Prefetti del Regno, 16 August 1872, Archivio di Stato Torino, Via Piave (AdSTP), Prefettura di Torino Gabinetto: Categoria Massime Affari Vari 1871-1929, 640/1.

Telegram from Interior Minister, General Director of Pubblica Sicurezza, Rome, to the Prefects of the Kingdom, 15 May 1890, ACdSR, Ministero dell'Interno, Polizia Giudiziaria, 1910-1912/12100.14, Busta 304: earlier telegrams attached.

T. Calissano, Circular no 99118 to the Prefects of the Kingdom, 21 August 1910, AdSTP, Prefettura di Torino, Gabinetto, Cat. Massime Affari Vari 1871-1929, Busta 640/1.

L. Luzzatti, Telegram received 26 August 1910 in Torino, AdSTP, Prefettura di Torino, Gabinetto, Cat. Massime Affari Vari 1871-1929, Busta 640/1.

Leonardo, Telegram from Rome, Divisione di PS (n. 12100.14) received 4 October 1910 in Torino, AdSTP, Prefettura di Torino, Gabinetto, Cat. Massime Affari Vari 1871-1929, Busta 640/1. 
Leonardo, Telegram from Rome, Divisione di PS (n. 12100.14) received 4 October 1910 in Torino, AdSTP, Prefettura di Torino, Gabinetto, Cat. Massime Affari Vari 1871-1929, Busta 640/1.

Prefect of Udine to the Ministero dell'Interno, Direzione Generale di PS, 24 August 1911, ACdSR Ministero dell'Interno 12100.14, Polizia Giudiziaria, 19101912, busta 306.

Recibido: 12 de noviembre de 2019

Aceptado: 12 de noviembre de 2019

Jennifer Illuzzi is Associate Professor of History at Providence College, USA. She researches the intersections of institutional power and Romani marginality in Germany and Italy as well as European gender history. Her publications include Gypsies in Germany and Italy 1861-1914: Lives Outside the Law (Palgrave MacMillan, 2014), "Stories of a Life Together: Romani groups and the poor in turn of the century Italian archival sources" (Ricerca Folklorica, 2019), and "Reimagining the Nation: Gendered Images of Italy and the Italo-Turkish War of 1911-12” (Gender and History, 2018). Jilluzz1@providence.edu 